\title{
Implementation of Inclusive Education in Learning Process at Senior High School Malang City, Indonesia
}

\author{
Ediyanto $^{1, \mathrm{a})}$, Aris Setiawan ${ }^{2, \mathrm{~b})}$, Irvan Budi Handaka ${ }^{3, \mathrm{c})}$, Nurul Hidayati Rofiah ${ }^{4, \mathrm{~d})}$, Suhendri ${ }^{4, e)}$ \\ ${ }^{1}$ Universitas Negeri Malang, Indonesia \\ ${ }^{2}$ Universitas Yudharta Pasuruan, Indonesia \\ ${ }^{3}$ Universitas Ahmad Dahlan, Indonesia \\ ${ }^{4}$ Hiroshima University, Japan
}

a)ediyanto.fip@um.ac.id, b)arissetiwan@yudharta.ac.id, c)irvan.handaka@bk.uad.ac.id, d)nurulhidayati@pgsd.uad.ac.id, ${ }^{\text {e)}}$ 1196070@hiroshima-u.ac.jp

\begin{abstract}
One of the Public Senior High Schools in Malang has been implementing an inclusive education system since 2009. This School has been trying to serve children with special needs hitherto. In one of the inclusive schools in Malang city, the number of students with special needs (the academic year 2017-2018) is recorded in the school document of 9 students with special needs and 37 students with special services (have health problems). However, it is indicated that the learning process in class is not suitable for the type of student needs in the class. This study aims to investigate the learning process in these inclusive schools. The current research is explained in a descriptive qualitative method. As a result, schools do not make curriculum modifications that are compatible with inclusive education. This school only has one special guidance teacher, and only he has attended a training program in inclusive education. In addition, there are indications that the teacher's attitude toward students with special needs is negative. The indication can be seen from the teacher's efforts in implementing learning. The teacher still uses a classical learning system that is not modified. Thus, it is necessary to improve services for students' diversity in schools, increase the number of special tutors, include them in inclusive education training programs, and make curriculum modifications that are appropriate for students with special needs. The teacher is also indicated to have a negative attitude towards students with special needs in the classroom.
\end{abstract}

Keywords:

\section{Introduction}

Inclusive education has been the focus of development by the Indonesian government since 2009 (Ediyanto et al., 2017). However, the inclusive education National school system in Indonesia is still implementing a service-learning model of learning outcomes with the completion of competencies. This system runs in classical learning 
(Ishartiwi 2010; Purbani, 2013). However, classical learning activities do not provide flexibility to inclusive learning. Though the curriculum implementation was adjusted, enriched, and adapted to accommodate the children with a special need, on the practical level, the existing classical learning cannot match the inclusiveness (Purbani, 2013). Inclusive education provides an education system that provides opportunities for all learners who have the disability and/or gifted to participate in education or learning in an educational environment together with the learners in general. Inclusive education policies and practices also in line with the movement to apply the principle of education for all.

Based on a preliminary study in inclusive schools at Malang City, one of the senior high schools in Malang City has implemented an inclusive education system. The school in the current study has officially become an inclusive school since 2009 . Since 2009, this school has been trying to serve children with special needs until now. The children who attend school are not only children who live in Malang but also some children living outside Malang City. As is the case with public schools, Its Schools carry out learning in the same system as other public schools. Nevertheless, this School turned out to be willing and able to accept and accommodate students with special needs. This school has experience in fostering students with special needs who are united with typical students.

Being an inclusive school is indeed not easy. At least, schools must prepare themselves with innovations so that children with special needs can follow the learning process well (Tarnoto, 2016). These innovations start from the introduction of inclusive education, identification of children with special needs, curriculum development, teaching methods, instructional media, teacher competencies, assessments, to academic and non-academic services that must be arranged in such a way and certainly requires a significant amount of time and money (Lisdiana, Hufad, \& Tarsidi, 2018).

The above data signifies community trust to educate their children in inclusive schools at Malang City. The people feel interested in including their children in this school because people see this school close to where they live, and people feel safe to allow their children to get the services of a friendly teacher to serve the child despite the many shortcomings in their child. The teacher accepts children with special needs with complete sincerity to educate and never complain and enough discipline. The treatment that teachers provide in educational and learning services is the same in all children. The total number of shadow teachers in this school is two persons. One special mentor counseled three low vision children and nine children slow to learn, and another special mentor led the four hyperactive children and two special intelligent students.

Based on the explanation above, it is essential to know the implementation of inclusive education in one of the inclusive schools in Malang city. This research aims to find out the learning process in an inclusive class setting, with the formulation of the problem "How is the learning process in Inclusive School at State Senior High School 
Malang City, Indonesia." At the same time, the focus of research is how the learning process in inclusion setting constraints the school in overcoming the constraints associated with the process learning.

\section{Methods}

The type of research used is descriptive qualitative research. According to Suharsimi (2005: 234), qualitative descriptive research is not intended to test a particular hypothesis but only describes" as is "about a variable, a symptom, or a state.

The subject of the study is the target under study. Classes observed in this study are classes that have students with special needs. In the interview process, interviews were conducted with three teachers taught in the classroom, which had students with special needs and one teacher assistant. In the documentation process, to support the completeness of the data required in this study then used the documentation related to the design, the process of teaching and learning activities, and evaluation in the classroom.

The validity of data obtained from the field is checked through specific criteria and techniques. So in determining the validity of the data required data inspection techniques, the implementation of inspection techniques can be done by discussing with teachers. According to Sanafiah (1993), by discussing the results obtained from research that has been implemented. Then, Triangulation compares the observation and interview results about inclusive learning with experts and other research results.

\section{Results}

\subsection{Learning Process in the School}

The teacher learning process in each classroom has different characteristics; teachers keep using the same curriculum as their grade level. The learning approach used in the teaching and learning process is classical. While children's different characteristics seem to be in the use of learning media have not been maximal, all children of different characters and teachers lack the motivation to students with special needs during the learning process. The seating arrangement of children in the classroom by teachers is deliberately told to sit with the more intelligent regular students to help them in a less complicated subject to understand. Special low vision students are accompanied by a teacher counselor, especially during the learning process. The work done by the classroom teacher lends a note or a friend's book to be told to re-learn at home with parents. In addition, the development of learning outcomes of children with special needs is only informed to parents who come to school when picking children home from school.

Based on a study in Inclusive School at Malang City, the children who attend school live in Malang, and some children live outside Malang City. This school has officially become an inclusive school since 2009. Since 2009, this school has been trying to serve 
children with special needs until now. The number of students with special needs (the academic year 2017-2018) is recorded in the school document of nine students with special needs and 37 students with special services. Consisting of nine students with special needs are two students with slow learner, three students with Autism, one student with hyperactive, and two gifted students (Table 1). Consisting of 37 students with special services are students with health problems such as asthma, bronchitis, symptoms of appendicitis, sinusitis, and typhus.

Each teacher is required to make the design of the lesson plan. In comparison, individual lesson plans are only for special guidance teachers to design. The lesson plan is developed in accordance with the competency standards of the Indonesian National Curriculum (Curriculum 2013). The lesson plan is tailored to the learning subjects. It means that each subject has its lesson plan.

Based on the observation in the learning process, the teacher delivered the subject matter to the students using the Learning Method and the assignment. Teachers do not use other methods. During the learning process, teachers do not create cooperative learning. So there is no cooperation between typically students and students with special needs. In addition, the typical student does not help students with special needs. The teacher asks the students to study independently. For students who do not understand the lessons, the teacher asks the teacher directly in the other classes, and very few see that teachers try to help students who do not understand the lesson.

The teacher's learning media in presenting the subject matter are packages of books, markers, and blackboards. The teacher does not use other learning media. These materials are taught to students based on the national curriculum. The subject matter is taken from textbooks with various authors who can assist in completing the material in accordance with the learning objectives. The subject matter between students with special needs is the same as typical students. The teacher uses Indonesian and also the local language. In written language, the teacher has used it well and delivered the material in an appropriate style.

Daily examinations in class are objective and short. The test is needed to read by the teacher and students' answers on each paper. Then the results of the exam are collected and examined by the teacher. This oral examination consists of the repetition of daily learning material. The test uses question and answer sheets for midterms and semesters-students' tests by the material taught. There are no differences in test questions between typically students and students with special needs. For low-grade students, students are not given a remedial exam. In the teacher's class, there are no product, performance, and portfolio assessments.

\subsection{Efforts to overcome constrain in the learning process (Inclusion Settings)}


Constraints perceived teachers in making a lesson plan that must be typed in for a few meetings (minimum for three weeks). A special guidance teacher designs the individual learning program. The problem is that the school has only one shadow teacher, while students with special needs spread in class X to XII. A special guidance teacher is also very difficult when assisting the different needs of students to vary. In addition, special guidance teachers also only once received training in inclusive education. Those special guidance teachers are also subject teachers who are trained as teachers for students with special needs.

In making lesson plans and individual learning programs, there is no effort that the teachers must make. The preparation of lesson plans is an obligation and responsibility that each teacher must design. Also, it is essential to make a modified lesson plan according to students with special needs in class. In terms of the number of special guidance teachers, the school does not plan to increase the number of special assistant teachers soon. Even if there is, special guidance teachers remain from class teachers. The class teacher is planned to be included in inclusive education training for various types of student needs.

Table 1 Data of Student with Special Needs

\begin{tabular}{lllll}
\hline No & \multicolumn{1}{c}{$\begin{array}{c}\text { Number of } \\
\text { Students }\end{array}$} & & Type of Special Needs & \\
\hline 1 & Student 1 & Autism & Mental Disability & Slow Learner \\
\hline 2 & Student 2 & Mild Mental Disability & Epilepsy & Slow Learner \\
\hline 3 & Student 3 & Scoliosis & & \\
\hline 4 & Student 4 & Hyperactive & Gifted & \\
\hline 5 & Student 5 & Spastic & Tremor & \\
\hline 6 & Student 6 & Idiopathic & & \\
& & Thrombocytopenia & & \\
\hline 7 & Student 7 & Puerperal & Autism & \\
\hline 8 & Student 8 & Asthma & Autism & \\
\hline 9 & Student 9 & Scoliosis & \\
\hline
\end{tabular}

A large number of students in the classroom and the existence of students with special needs in the classroom causes teachers to use various methods in delivering the subject matter to the students. Teachers make no effort to overcome obstacles in using varied learning methods. Teachers still use the method of lecturing and assignment. While the teacher does the work when the hyperactive students shout in the class, ask the other students to pay attention to the teacher explaining the material in front of the class. In the effort to silence the hyperactive students the teacher asks for help from the parents. At the same time, the business is done by special guidance teachers in overcoming the obstacles faced by low vision students in writing that are helping to hold the child's hand 
to write. The effort undertaken to overcome students with slow learner in learning Indonesian and Mathematics helps students read and count.

Constraints experienced by students with hyperactive difficulty to muffle emotions if experiencing difficulty in completing the teacher's task. Nevertheless, children with learning difficulties are difficulties in reading and counting on physics, chemistry, and mathematics. The applied system is a moving class. With every change of learning hours, students will move to another class. There are no facilities that support students with special needs for switching classes at the lesson turn. There are no significant obstacles encountered in using the learning media or in the manufacture of media to the material being studied for other constraints. The teachers do not make a great effort to overcome the obstacles of learning media. The teachers use only simple media and pictures. For example, in science lessons about natural subjects around the environment, the teacher only shows pictures in books.

Teachers do not experience any constraints in determining subject matter to students. The subject matter between typically students and students with special needs is the same as referring to the Curriculum 2013 dan unmodified. Generally, the spoken language used in the learning process is Indonesian. Sometimes teachers experience constraints that there are children who do not understand the Indonesian language used by teachers then the teachers use the local language (Javanese Language). The absence of teachers performing product assessments to students in the classroom and insufficient time allocation for subjects requiring product assessment. No other attempt by the teacher to overcome obstacles in doing product assessment, portfolio to students.

In the current study, it was found that the teachers have problems with students with special needs. They said the teacher's time being monopolized by special needs students and the learning process becomes disturbed. Nine teachers mentioned the lack of facilities because it is challenging and expensive to modify school buildings. Teachers said the disturbance of typical students by the presence of students with special needs in the classroom. Other obstacles that were discussed include less conducive classes, the inability of students with special needs to study adequately, the lack of time given to teachers to learn about special needs students and inclusive education, and promiscuity cases. Furthermore, teachers talked about parents' expectations of their children with special needs, the needs of special mentor teachers in schools, difficulties in making assessments, new admissions systems, and the unavailability of curricula.

\section{Discussion}

The inclusion school designs consist of the lesson plans and Individual learning program, in which the class teacher designs the lesson plan for all children. A special guidance teacher designs the Individual learning program. Teachers feel that designing lesson plans and Individual learning program is their responsibility. In comparison, the 
effort is the existence of teacher awareness of responsibilities by classroom teachers or teacher assistants.

In classrooms, all students should learn the various skills that are essential for achieving success in life (Hannah, 2013). In a regular classroom, the teacher must teach students about social skills to promote positive interactions among students (Lindblad Jr, 1994; Ferguson, 2014). Thus, for all students, an inclusive classroom is a place to experience a sense of belonging and a place to practice using social skills (Parekh, 2014) and promote a favorable climate for friendship (Underwood, 2013). A regular classroom for all students (including students with special needs) can support self-organization (Greenstein, 2013). The classroom environment is a critical aspect of inclusive classrooms' success (Hannah, 2013). Thus, inclusive classroom environments need to be modified to accommodate all students (Parekh \& Underwood, 2015). The success of students in the classroom is determined by teachers who can create classes that support learning. Comfortable classrooms can support student success in learning (Hannah, 2013; Bucholz \& Sheffler, 2009). Therefore, the presence of students with special needs in the classroom should not be a barrier to other students' progress in the classroom.

Inclusive education is not assimilation (Slee, 2018). It is not intended to normalize students or to create sameness within a classroom but rather to celebrate diversity among all students (Parekh \& Underwood, 2015). In inclusive classrooms, teachers should exhibit professional competence (Zulfija, Indira, \& Elmira, 2013). Teachers in inclusive schools must be organized and responsive to all students in the classroom (Artiles, Kozleski \& Waitoller, 2011). The teacher must learn and practice student-centered pedagogy (McDonnel, 1998; as cited in Mitchell, 2010) and teach the material in the curriculum and social skills (Hannah, 2013).

The method used by the classroom teacher has not varied. Only use lecture method and task assignment, so the children become bored, and some children do not pay attention to the teacher in learning. The constraints are because of the large number of students with various characteristics and lack of understanding of teachers' classes about students with special needs. Moreover, the other case is the lack of facilities to support a student with special needs. Teachers are professionals. In inclusive classes, they should identify and accept special needs students, provide them with a favorable learning environment, and involve them in almost all regular classroom activities (Tyagi, 2016). However, in reality, as Furuta and Alwis (2017) have mentioned, teachers in Sri Lanka experienced stress when typical students and students with special needs were together in the classroom. The study found that $75 \%$ of teachers had difficulty coping with students with special needs.

In this school, the media used adapted to the learning materials. There are no obstacles in getting and using the learning media, so there is no other effort to overcome it, especially for multiple disability students. They need to be accompanied by a teacher 
assistant. The teacher must trust all students to be responsible and learn actively. For example, students with visual impairments can learn science through appropriate methods if given the proper facilities (Ediyanto \& Kawai, 2019). Learning media, such as assistive computer-based technology (Johnstone, Altman, Timmons, \& Thurlow, 2009, Azeta, Inam, \& Daramola, 2018, Eligi \& Mwantimwa, 2017), verbal communication and physical help (Suveren-Erdogan \& Suveren, 2018), orientation, and mobility skills (Arslantekin, 2017), and Braille (Mobaraki, Nazarloo \& Toosheh, 2017, Nannemann, Bruce, Hussey, Vercollone, \& McCarthy, 2017) can also help these students to understand many concepts. Furthermore, students with autism spectrum disorder can learn science through useful strategic mathematics (Su, Lai, \& Rivera, 2012), computer-based interventions (Aliee, Jomhari, Rezaei, \& Alias, 2013), Science eText (Knight, Wood, Spooner, Browder, \& O’Brien, 2015), and the touch math technique (Yikmis, 2016).

Material is the same for all children taken from the package book by referring to the Curriculum 2013. There is no specific curriculum for the student with special needs. Because the material is the same for all children, the teacher does not experience significant constraints. The curriculum used must comply with national education standards. The curriculum standard in Indonesia is the K13 curriculum. However, in the assessment, students with special needs have different assessment standards. Ideally, teachers in an inclusive school consist of a classroom teacher, special guidance teachers, and an ortho-pedagogic teacher. Facilities in inclusive schools should be tailored to students with special needs. The Indonesian government's commitment is to provide inclusive education as well as possible and periodically provide appropriate facilities (Ediyanto et al., 2017). The types of assessment in the inclusive class are written assessment, performance, product, and portfolio assessment (Tarmansyah: 2007). Based on the facts in the field, the teacher only conducted an oral test. Teachers do not have performance assessments, product ratings, and portfolio assessments. That teacher's activity is due to the teacher's lack of understanding of the assessment. The Teachers did not undertake efforts to overcome related constraints in their lack of understanding of performance assessment, product, and portfolio assessment.

\section{Conclusion}

The teacher is indicated to have a negative attitude towards students with special needs in the classroom. The teacher considers students with special needs to interfere with the implementation of learning in class. Based on the explanation of lessons in inclusive classroom settings in Malang that the design is learning in inclusive settings is still the same as the National Curriculum (Curriculum 2013) and not modified according to the needs of students, including a lesson plan and individual learning programs. The learning method does not vary, and the school uses a mobile classroom system and just simple learning media. Seating arrangements have varied. The material is taken from the textbooks, and the special guidance teacher makes simple material, while the teacher's assessment is only an oral assessment. The teacher does not conduct performance 
appraisals, product assessments, and portfolio assessments. Constraints faced include many students in the class and hyperactive, autistic, and slow students, which causes teachers to be constrained in using various teaching methods. In addition, the lack of teacher understanding of how to teach students who are in need in class and the lack of teacher knowledge on how to do portfolio assessments. Only special guidance teachers have attended training in inclusive education training programs.

\section{Future Directions}

Concerning the results of the current study, the researchers gave future directions as follows:

1. It needs more observation in the inclusive class to illustrate the condition of inclusion classes in Indonesia clearly.

2. Because indicated teachers have a negative attitude in inclusive education, then to prove it, we need to do research about teacher attitude toward inclusive education.

3. An inclusive education training program is conducted to add special guidance teachers in schools.

\section{References}

Aliee, Z. S., Jomhari, N., Rezaei, R., \& Alias, N. (2013). The Effectiveness of Managing Split Attention among Autistic Children Using Computer Based Intervention. Turkish Online Journal of Educational Technology-TOJET, 12(2), 281-302.

Arslantekin, A, B. (2017). Evaluation of the Level of Students with Visual Impairments in Turkey in Terms of the Concepts of Mobility Prerequisites (Body Plane/Traffic). Eurasian Journal of Educational Research, 67, 71-85.

Artiles, A. J., Kozleski, E. B., \& Waitoller, F. R. (2011). Inclusive education: Examining equity on five continents. Cambridge: Harvard Education Press.

Azeta, A. A., Inam, I. A., \& Daramola, O. (2018). A Voice-Based E-Examination Framework for Visually Impaired Students in Open and Distance Learning. Turkish Online Journal of Distance Education, 19(2), 34-46.

Bucholz, J. L., \& Sheffler, J. L. (2009). Creating a warm and inclusive classroom environment: Planning for all children to feel welcome. Electronic Journal for Inclusive Education, 2(4), 1-13.

Ediyanto, E., Atika, I. N., Kawai, N., \& Prabowo, E. (2017). Inclusive Education in Indonesia from the Perspective of Widyaiswara in Centre for Development and Empowerment of Teachers and Education Personnel of Kindergartens and Special Education. IJDS: INDONESIAN JOURNAL OF DISABILITY STUDIES, 4(2), 104-116.

Ediyanto, E., \& Kawai, N. (2019, June). Science learning for students with visually impaired: A literature review. In Journal of Physics: Conference Series (Vol. 1227, No. 1, p. 012035). IOP Publishing.

Eligi, I., \& Mwantimwa, K. (2017). ICT accessibility and usability to support learning of visually impaired students in Tanzania. International Journal of Education and Development using ICT, 13(2). 
Ferguson, H. (2014). Researching social work practice close up: Using ethnographic and mobile methods to understand encounters between social workers, children and families. The British Journal of Social Work, 46(1), 153-168.

Furuta, H., \& Alwis, K. A. C. (2017). Teaching students with special educational needs in an inclusive educational setting in Sri Lanka: Regular class teachers' view. Journal of International Cooperation in Education, 19(2), 1-18.

Greenstein, A. (2014). Is this inclusion? Lessons from a very „special" unit. International Journal of Inclusive Education, 18(4), 379-391. DOI: 10.1080/13603116.2013.777130

Hannah, R. 2013. "The Effect of Classroom Environment on Student Learning." Honors Theses. Paper 2375.

Ishartiwi. 2010. Implementasi Pendidikan Inklusif Bagi Anak Berkebutuhan Khusus dalam Sistem Persekolahan Nasional. Jurnal Pendidikan Khusus, 6(2), 1-9.

Johnstone, C., Altman, J., Timmons, J., \& Thurlow, M. (2009). Students with visual impairments and assistive technology: Results from a cognitive interview study in five states. Minneapolis, MN: University of Minnesota, Technology Assisted Reading Assessment (TARA).

Knight, V. F., Wood, C. L., Spooner, F., Browder, D. M., \& O'Brien, C. P. (2015). An exploratory study using science eTexts with students with autism spectrum disorder. Focus on Autism and Other Developmental Disabilities, 30(2), 86-99.

Lindblad Jr, A. H. 1994. "You Can Avoid the Traps of Cooperative Learning." The Clearing House 67 (5): 291-293.

Lisdiana, A., Hufad, A., Tarsidi, D., \& Aprilia, I. D. (2019, July). Differentiated Instruction: An alternative learning approach for all learners in inclusive setting. In 2nd International Conference on Educational Sciences (ICES 2018) (pp. 19-21). Atlantis Press.

Mitchell, D. (2010). Education that fits: Review of international trends in the education of students with special educational needs. Christchurch, New Zealand: University of Canterbury. $\quad$ Retrieved from http://www.educationcounts.govt.nz/_data/assets/pdf_file/0016/86011/MitchellReview-Final.pdf

Mobaraki, M., Nazarloo, S. A., \& Toosheh, E. (2017). A Comparative Analysis of Contracted versus Alphabetical English Braille and Attitudes of English as a Foreign Language Learners: A Case Study of a Farsi-Speaking Visually Impaired Student. Journal of Visual Impairment \& Blindness, 111(5), 471-474.

Nannemann, A. C., Bruce, S. M., Hussey, C., Vercollone, B. S., \& McCarthy, M. (2017). Oral Braille Reading Decoding Strategies of Middle School Students Who Are Blind or Have Low Vision. Journal of Visual Impairment \& Blindness, 111(3), 284-288.

Parekh, G. 2014. Social citizenship and disability: Identity, Belonging, and the Structural Organization of Education (Unpublished doctoral dissertation). York University, Toronto, Ontario, Canada. Retrieved from http://yorkspace.library.yorku.ca/xmlui/bitstream/handle/10315/28217/Parekh_G illian_G_2014_PhD.pdf?sequence=2 
Parekh, G., \& Underwood, K. (2015). Inclusion: Creating school and classroom communities where everyone belongs. Research, tips, and tools for educators and administrators. (Research Report No. 15/16-09). Toronto, Ontario, Canada: Toronto District School Board.

Purbani, W. (2013). Equity in the classroom: The system and improvement of inclusive schools in Yogyakarta. Indonesia. US_China Education Review B, 3(7), 507-518.

Sanafiah. 1993. Penelitian Kualitatif. Malang : Universitas Brawijaya.

Slee, R. (2018). Inclusive education: From policy to school implementation. In Towards inclusive schools? (pp. 30-41). Philadelphia, PA: Routledge.

Su, H. F. H., Lai, L., \& Rivera, H. J. (2012). Effective Mathematics Strategies for Pre-School Children with Autism. Australian Primary Mathematics Classroom, 17(2), 25-30.

Suharsimi, A. (2005). Manajemen penelitian. Jakarta: Rineka Cipta.

Suveren-Erdogan, C., \& Suveren, S. (2018). Teaching of Basic Posture Skills in Visually Impaired Individuals and Its Implementation under Aggravated Conditions. Journal of Education and Learning, 7(3), 109-116.

Tarmansyah, S. (2007). INKLUSI: Pendidikan Untuk Semua. Jakarta Dep. Pendidik. dan Kebud. RI.

Tarnoto, N. (2016). Permasalahan-permasalahan yang dihadapi sekolah penyelenggara pendidikan inklusi pada tingkat SD. Humanitas: Jurnal Psikologi Indonesia, 13(1), 5061.

Tyagi, G. (2016). Role of teacher in inclusive education. International Journal of Education and Applied Research, 6(1), 115-116.

Yıkmış, A. (2016). Effectiveness of the touch math technique in teaching basic addition to children with Autism. Educational Sciences: Theory \& Practice, 16, 1005-1025.

Zulfija, M., Indira, O., \& Elmira, U. (2013). The professional competence of teachers in inclusive education. Procedia-Social and Behavioral Sciences, 89, 549-554. 